DoI: http://dx.doi.org/10.11157/sites-vol13iss2id327

- ARTICLE -

\title{
TE AHU - A MEETING PLACE
}

\author{
Avril Bell ${ }^{1}$
}

\begin{abstract}
In 2012 a new community complex opened in Kaitaia, housing the local museum, library, $i$-Site, hall, theatre and Council offices. This complex is very obviously a meeting place for people of the community and out-of-town visitors. But the site on which the building, Te Ahu, stands has a much longer history as a meeting place. In this paper I outline this history in light of recent theorising about the intertwined work of space, time, people and things in the liveliness of place. This history foregrounds the ways in which the changing nature of this meeting place marks shifting indigenous and settler relations through time. Recounting the stories of this one, particular, place, my wider aim is to give a sense of the enmeshment of the settler society present in the ongoing stories of the living pasts of place.
\end{abstract}

Keywords: place; history; spatio-temporal events; haunting; indigenous-settler co-existence

Places pose in particular form the question of our living together. And this question [...] is the central question of the political. (Massey 2005,151$)$

The entire complex [Te Ahu] and the environment around it should live and breathe the cultural and historical roots of Te Hiku and Muriwhenua. (Piripi 2010, 4-5)

\section{INTRODUCTION}

It seems serendipitous that $T e A h u$ ended up on a site so rich in history. The charitable trust that led the development of this new community resource centre in my hometown, Kaitaia, had a number of possible sites in mind for the complex. In late 2008 it was finally decided to build on a site adjacent to the 
existing Community Centre, on land owned by the Far North District Council (FNDC). This was a pragmatic and political decision. The old Community Centre was becoming dilapidated and needed major renovation or replacement. The renovation could be undertaken on the back of the Te Ahu project, which was being significantly funded by charitable monies. Further, the site was already public la our living together nd, designated in the FNDC Long Term Plan as a social and sports hub. But while the decision about the site was fundamentally a practical one, the name the complex was ultimately given, $\mathrm{Te}$ $A h u$, spoke to a significance and a history that went way beyond pragmatics. It seems to me a kind of magic that $\mathrm{Te} A h u$ came into being. On another site it may well have had a different name and historical resonance, or no such resonance at all: here, on the old riverbed at the edge of town it became Te $A h u$, a new materialisation of the long history of this place as a meeting place.

Any consideration within settler colonial contexts of 'meeting places' immediately brings to mind Mary Louise Pratt's highly influential concept of 'contact zones', which she defines as 'social spaces where disparate cultures meet, clash, and grapple with each other often in highly asymmetrical relations of domination and subordination' $(2008,7)$. Pratt $(2008,8)$ highlights the 'interactive and improvisational' qualities of the encounters between peoples in contact zones, and sees these social spaces as sites in which ongoing relations are established, albeit that these relations are fraught with conflict. Importantly, against the idea of colonised peoples as passive victims, Pratt explains that her choice of the word 'contact' is intended to foreground the agency of the colonised people in these encounters (ibid). Each of these features of Pratt's concept is significant in the history of the land on which Te Ahu stands.

However, on its own this concept cannot encompass all the dimensions of the Te Ahu site as a meeting place. Pratt's 'spaces' or 'zones' are purely social, eliding the role of geographical place in colonial contacts. In this paper I want to also briefly consider the role of geography itself as a significant actor in the creation of $T e A h u$ as meeting place. Te $A h u$, as geographical place, is a conjuncture of location (specific and finite), materiality (water, land, building, roads, paths) and of the layering of stories, names and meaning, as people have travelled across, met and interacted, and in so doing, contributed to the becoming of this place (Gieryn 2000, 464-5; Massey 2005, 130). These stories begin in the era of Māori occupation prior to colonisation, and change and continue with the arrival of Pākehā and the interactions between indigenous and settler peoples.

This paper arises out of research I have been undertaking since 2011 explor- 
ing the involvement of Muriwhenua iwi in the development of Te Ahu. The research has been driven particularly by an interest in how the non-Māori players in the development have responded to iwi desires for a partnership relationship in this building project. ${ }^{3}$ This project has been ethnographic in nature and has involved over 40 interviews with some of the key players in the development and members of the wider community. This paper is my attempt to record what I have learnt in the process of my research about the histories and stories of meeting where Te Ahu now stands, creating a meeting place, temporally and spatially open and unfinished, connecting people in and through place, and connecting also to the wider and larger stories of settler colonialism and indigenous survival that extend well beyond this specific location.

The paper is organised chronologically, beginning with the geological features of the site itself and tracing significant stages in the creation of this site as a meeting place from pre-colonial times to the present. I am inspired by Doreen Massey's (2005) arguments for the openness and processual nature of place, as something that is never 'settled' but always in motion. Massey sees place as accumulating layers of history, and I illustrate that accumulation via this chronological account. But she writes also against the common view that time is where all the action is, with place being merely the stage set on which the action happens. Place, for Massey, is an actor in the stories of 'our living together', stories that are not only temporal but importantly spatial. Edward Casey (1996, 26) evocatively describes this power of place:

Place is the generatrix for the collection, as well as the recollection, of all that occurs in the lives of sentient beings, and even for the trajectories of inanimate things. Its power consists in gathering these lives and things, each with its own space and time, into one arena of common engagement.

For Casey this gathering power of place is not only the power to 'amass' people and things, but also to order them, to 'hold' them in and out of place, to include, exclude and marginalise, via particular configurations (Casey 1996, 24-6). The concept of 'configuration' appears in Massey's work also, to point to the temporary, processual nature of any particular spatial arrangement and relation. In the sections that follow I trace some of the significant configurations (of people and place) so far in the becoming of this site as a meeting place.

Another reason I am drawn to Doreen Massey's work, is because of her concern with the ethics and politics of 'our living together' in contexts of diversity. 
Massey argues for a view of space that recognises and respects the 'actually existing multiplicity' that space presents us with $(2005,69)$. Here she draws on Johannes Fabian's important formulation of the 'coevalness', or contemporaneity, of different peoples, ways of being and temporalities (see Massey 2005, 69-70). I also draw attention to this coevalness, particularly of linear settler time and a Māori temporality in which the past continues to be active in the present. That temporality is evident in accounts of the presence of ghosts who haunt $\mathrm{Te} A h u$, and who I argue, following Derrida, are a provocation to precisely the kind of ethical approach to 'our living together' that Massey calls for.

\section{THE BEND IN THE RIVER}

The gathering power of the Te Ahu site begins with the fact that this is a flat, open expanse of land, and crucially also that it is itself a meeting place of river and land. This gathering of river and land made this site accessible, facilitating travel to and from by waka (canoes) and boats, as well as by walking trail and, later, by road. These intersecting trails and river paths point to the way that part of the openness of place is how it links with other places - 'here' connects to 'there' - and how the local and particular connect with larger, sometimes global forces and movements, as people come and go (Massey 2005).

The meeting of land and river at $\mathrm{Te} A h u$ means also that this is a changing geographical site, prone to flooding and shifting river courses. Historically, no doubt, the river course has moved across this flood plain at many places and times as floodwaters and erosion have changed the contours of land and water. But during the twentieth century the river was also gradually straightened as part of flood mitigation work, first in the 1920s, with further straightening and filling in of the old river bed then carried out in the 1970s and $1980 \mathrm{os}$ (Shepherd 1988, 15, 27). This work means that the building, Te Ahu, now stands, in part, on what was once riverbed. But before this straightening of the river, since the time of early colonial contact, the site where Te Ahu now stands was a sharp bend at which the river almost doubled back upon itself (see Figure 1). I imagine this distinctive topography being a reason why, in the pre-colonial era - before written maps and signposts, let alone GPS - this site became a meeting place.

Some of the stories gathered at the Te Ahu site are signified in the names of the streets now intersecting nearby, replacing the older trails and paths. There is the prosaically named South Rd, connecting Kaitaia to places further south, and Church Rd and Matthews Ave, both speaking to the missionary 


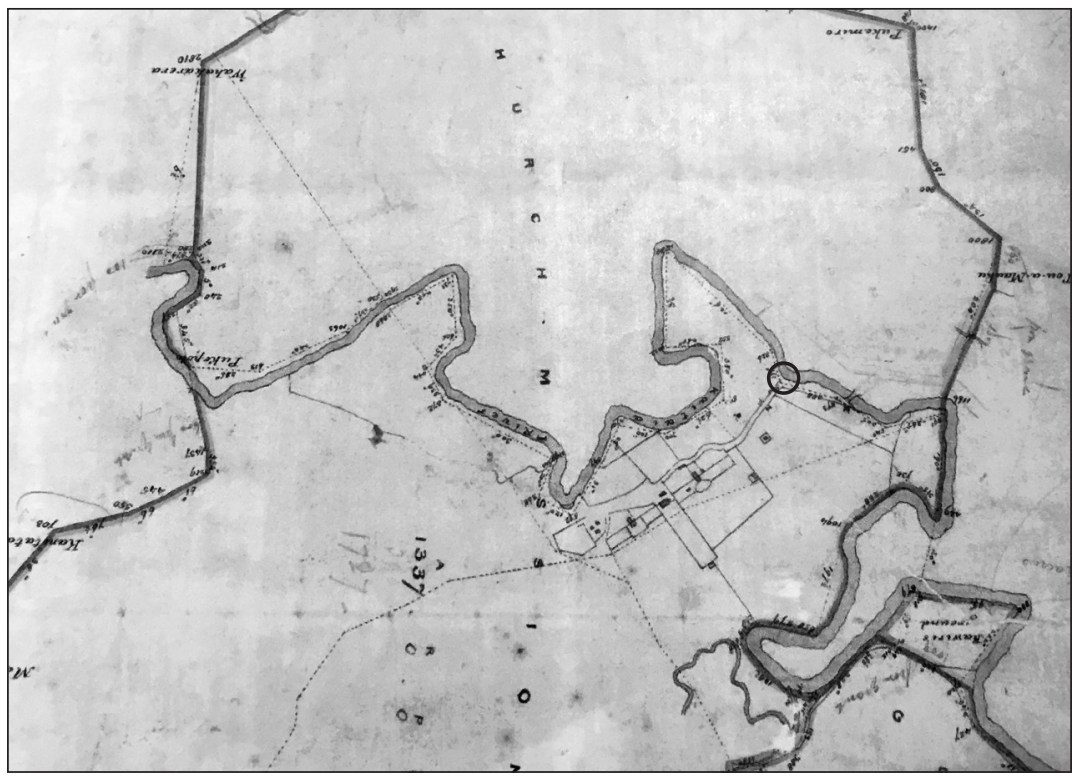

Figure 1. Detail of survey of CMs land, J(?). Kempthorne, Auckland 1856 (Te Ahu location at circle). Te Ahu Heritage Museum \& Archive, vf490/50.

history of the area. ${ }^{4}$ Nearby also are Mission Place, Panakareao St and Te Ahu St. Alongside this most recent layering of names, part of the colonial project of 'linguistic settlement' (Berg and Kearns 1996, 99), older names and locations continue to resonate, brought back to the fore with the development of the $\mathrm{Te}$ Ahu complex.

\section{TE IKA HUNUHUNU \& TE AHU}

Looking through the local archives I see 'Te Ahu' given as the name for the area now occupied by the town of Kaitaia. ${ }^{5}$ It was clearly a name in use at the time of European settlement, and it is this historical connection that led to the decision to name the complex Te Ahu. But while this was the name of the general area, this stretch of the Awanui River had its own name. ${ }^{6}$ As Haami Piripi, Chair of Te Rūnanga o te Rarawa, and a key player in the Te Ahu development, explains:

The proper name for the place was Te Ika Hunuhunu, which was a bend in the river that our rangatira used to sit at to determine the allocation of spoils of war, of different responsibilities or deci- 
sions, and they'd come and talk about it here, at the bend in the river. (Interview, 21/4/12)

So from pre-colonial times, Te Ika Hunuhunu was a meeting place, a site of the coming together of people from different whānau (families) and hapū (subtribes). In my conversations with local residents (both Māori and non-Māori), those who were knowledgeable about this early history frequently alluded to the practice of kairarawa on this site, the killing and eating of prisoners to replenish the mana (prestige) of the victors of war (Marsden 1992, 127), as one of the processes involved in the allocation of 'the spoils of war' at this time. Thus, even before the establishment of the colonial contact zone, Te Ika Hunuhunu was a place of politics, conflict and violence.

When 'Te Ahu' was being discussed as a possible name for the complex, Haami argued that no English translation or supplementary English name should be provided. That this was acceptable to the non-Māori community was considered politically significant as a marker of the changing place of Māori within the community. Not providing a translation was also important to avoid oversimplifying the rich connotations of the name, as inevitably a short translation would (Haami Piripi, interview, 21/4/12). Resorting to the Māori Dictionary Online I find the following definitions of ahu: to heap up, or a heap, or mound (including a sacred mound); to tend, foster, nurture, fashion; to treat (as in treating a wound); to move in a certain direction, face towards, extend, stretch from. Notions of meeting and relation are redolent in each of these meanings, which variously point to processes of creating and gathering, of connecting and orienting, and moving towards or away. In these ways the name is perfect for a new complex that, following the trend towards convergence of cultural heritage institutions (see Wellington 2013), brings together many of the area's major cultural, social and political functions (museum, library, tourist information centre, hall, theatre, meeting rooms, FNDC Service Centre) and also re-gathers the five iwi of Muriwhenua at the heart of the community alongside the two settler peoples, Pākehā and Dalmatian. Where Māori have long been pushed to the political and economic margins of the community, Te Ahu is part of a process of return in the exercise of tribal mana over the area and Muriwhenua more broadly. ${ }^{7}$

THE COLONIAL HISTORY OF THE SITE

Throughout the colonial era, the site on which $T e A h u$ now stands continued to be a significant meeting ground, becoming central to the establishment of permanent relationships between Māori and Europeans with the arrival of 
the first missionaries. In 1834, after a number of visits, Church Mission Society (CMs) missionaries, Joseph Matthews and William Gilbert Puckey, established their mission station in this area. There are different accounts of whether the missionaries were invited or simply arrived. The Matthews family history, The Matthews of Kaitaia $(1939,42)$, tells the story that the missionaries arrived uninvited (on a Sunday) and were threatened with being killed and eaten until the power of Matthews' sermon led those present to change their minds. The Waitangi Tribunal gives a different account. They argue that it is quite possible the missionaries came at the invitation of Rarawa ariki (paramount chief), Panakareao. This would reflect the strategic goals of the northern iwi leadership at this time, leading up to the 1835 He Whakaputanga, The Declaration of Independence of the United Tribes, and fits with historical evidence that this was a period when Pākehā settlers were sought by Māori leaders as both mana-enhancing and a source of trade opportunities (Waitangi Tribunal 1997, $40,48,57)$.

The land on which the mission station was established included the hill site the Anglican Church and cemetery still occupies, as well as a large portion of the flat riverside land, Te Ika Hunuhunu, where Te Ahu stands, on which the missionary families and their Māori neighbours established an orchard, hay paddock and wheat field (see Figure 2). In terms of the land transaction between Panakareao and the missionaries, the Waitangi Tribunal concluded that this (the first colonial land transaction in Muriwhenua), like others in this pre-Treaty era, was not undertaken within a western legal private property framework, but according to the concept of tuku whenua:

[Land] given to bring people into the hapū for the hapū's long-term advantage. It was claimed that reference to a tuku of land, a 'tuku whenua' as it is described in the deeds, would have conjured up that purpose. It is not just that Māori had no word for 'sale' but more, that the word the missionaries chose for sale, tuku whenua, in fact had another meaning already. (Waitangi Tribunal 1997, 73)

Tuku whenua transactions are 'rather like a lease but nothing like a sale' (Waitangi Tribunal 1997, 73) and are seen as binding the parties into ongoing relationships and mutual responsibilities. Thus, Panakareao granted the mission families enough land, not just for the mission itself, but for their children to farm also as they reached adulthood, with the expectation of ongoing commitment from the mission families to the welfare of the hapū. Rather than transferring authority over the land to the newcomers, tuku whenua binds and obliges them to the hapu and is an enactment of the rangatiratanga (chiefly au- 
thority) of the tribal leaders making the agreement (Waitangi Tribunal 1997, 66, 118). ${ }^{8}$ The Waitangi Tribunal also report that this understanding was shared by the missionaries themselves (1997, 71-2, 159-60) and was confirmed by Captain Fitzroy (later Governor of NZ) in 1838: 'It is a sort of conditional sale, such as, "we sell them to you to hold as long as we shall permit you"' (Waitangi Tribunal 1997, 67). This land-sharing/land use agreement between chiefs and missionaries was the first significant re-configuration of land and people of the colonial era, bringing a new use to the land at Te Ahu and a new people into a relationship of co-existence with the local hapū.

Six years after the mission was established, on 28 April 1840, a further significant meeting took place when around 500 local Māori gathered outside William Puckey's house to debate Te Tiriti o Waitangi. ${ }^{9}$ Panakareao arrived the evening before to question Puckey and the government officials closely about the nature of the treaty and particularly the word 'sovereignty'. A range of views was canvassed in the debate, and Willoughby Shortland, representing Governor Hobson at Kaitaia, assured the gathering 'The Queen will not interfere with your native laws or customs' (Waitangi Tribunal 1997, 114). Panakareao

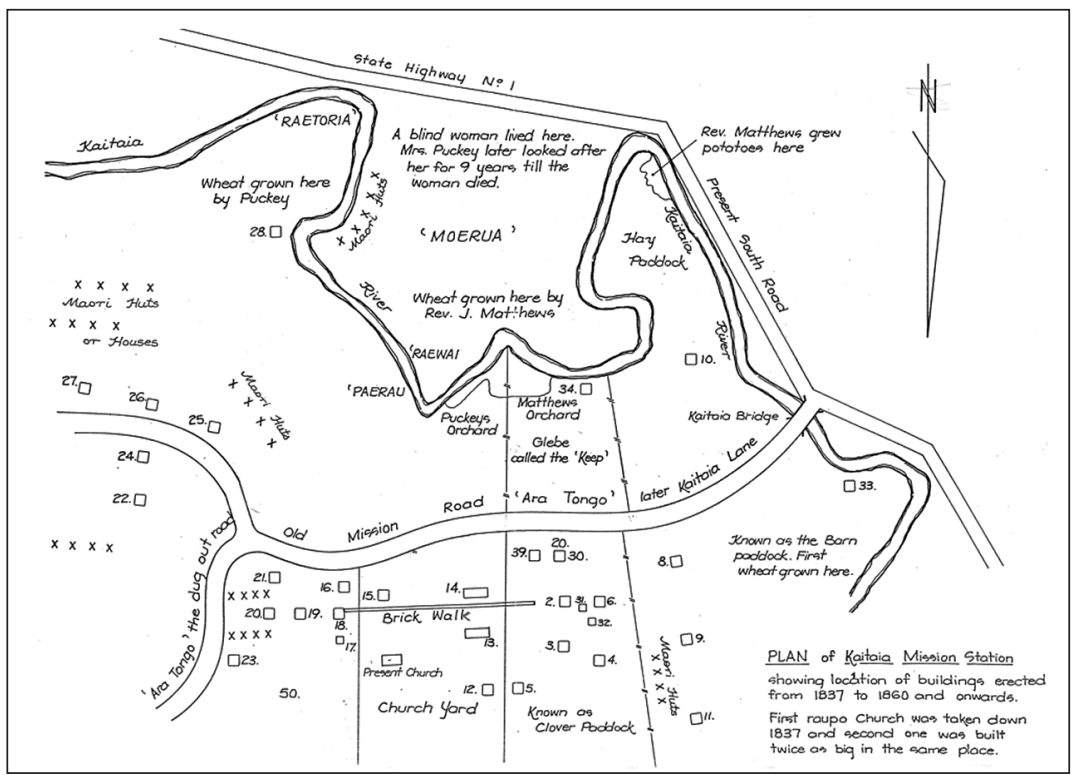

Figure 2. Plan of Kaitaia Mission Station, Te Ahu Heritage Museum \& Archive, VF490/50. 
spoke last, playing a leading and decisive role, and famously explaining his understanding of the concept of sovereignty as 'The shadow of the land goes to the Queen, but the substance remains with us. Ultimately, sixty-one rangatira signed Te Tiriti at Kaitaia, amongst them Panakareao's chiefly wife, Erenora, one of the few known women signatories.

\section{'The golden age'?}

From their statements and actions, and also those of the missionaries, it is clear that at the time of the establishment of the mission station and in the ensuing decades, Mãori understood that they continued to exercise their own rights over this land. They shared the land with the newcomers to their mutual advantage and, in fact, Panakareao and others continued to live on and use the land alongside the missionaries for at least another 25 years and probably longer (Waitangi Tribunal 1997, 66, 159-60). Panakareao established two of his fighting chiefs in residence, Rawiri Tiro and Kepa Waha, to protect the missionaries (Waitangi Tribunal 1997, 66) and 'Rawiri's ground' is recorded as being cultivated as late as 1856 (Waitangi Tribunal 1997, 153,160) and remained visible on maps of the area drawn in the 188os (see 'Māori huts' in Figure 2).

In his history, The First 100 Years, Matthews' descendant Harold Stuart Matthews, describes the 1850 os as the 'Golden Age' of the mission station (1956, 20-22). His undoubtedly Eurocentric view describes it as 'a gem of civilisation set in wild nature' and talks of Māori having 'accepted Christianity' and being 'a civilised people'. He talks also of the economic well-being of Māori during this period: 'They grew wheat and other European food crops and owned a small vessel called Fairy to take their surplus produce to Auckland' (Matthews $1956,20)$.

Other documentary evidence affirms Matthews' account. When Ernest Dieffenbach visited the region in 1840 during his travels in New Zealand, he spoke positively of Māori agriculture in the north and expressed his confidence that if the government kept to its commitment (made at the time of the Treaty signing) to limit the land holdings of any individual settler to 2,500 acres and to return the 'surplus' from the early (larger) land transactions to Māori, the 'government will have no difficulty in acquiring a fine agricultural district' (Waitangi Tribunal 1997, 155). Twenty-eight years later in 1868, William Bertram White, Resident Magistrate from 1848 to 1878 , reported to the House of Representatives on the 'quantities of native produce being sent to Mangonui to supply the wants of the numerous whalers visiting the port, besides wheat, corn and onions exported to Auckland and even Sydney' (AJHR, 1868, A-4, 36, 
cited Waitangi Tribunal 1997, 185). The era of tuku whenua was clearly one in which Māori flourished economically as they took on the new opportunities afforded by their Pākehā neighbours, although inter-tribal wars and, more significantly, European diseases also took their toll on the population and the political organisation of Mãori society during this period (Ballara 2003).

\section{Settler domination 'on the ground'}

This situation was not to last. From the time Te Tiriti was signed, Crown representatives increasingly acted on the assumption that the Crown now held radical title to all New Zealand lands and that pre-Treaty land transactions, such as that of the Kaitaia Mission Station, were to be interpreted according to British law. This was a gradual process of change, as land boundaries were progressively hardened and European possessive relations to land were asserted, so that by the end of the nineteenth century settler interests dominated the area and Māori were pushed to the margins.

The imposition of settler law began with the Land Claims Ordinance, 1841, which set out to investigate and legalise pre-Treaty land transactions. In Muriwhenua a commission of inquiry was led by Colonel Edward Godfrey, a new-comer to the country with no knowledge of Māori law and custom and completely reliant on his translator to understand Māori viewpoints. Māori were keen to present their views on landholdings to Godfrey and to gain recognition of their rights, but the Commission failed to take Mãori interests into account. Instead, its scope was restricted to ensuring equity amongst European purchasers, making sure that no one individual secured huge swathes of land. Settler holdings were limited to 2,500 acres, the Crown claiming the remaining lands from the early land transactions as 'surplus lands' rather than returning them to Māori as would have been more in keeping with the tuku whenua transactions (Waitangi Tribunal 1997, 122-8). The Tribunal $(1997,122)$ argues the Godfrey Commission was insufficient, in all circumstances, to compel the full examination that was needed if Māori law was to be upheld, and Māori interests protected, as the Treaty of Waitangi required'. Thus, already, within one year of signing the Treaty, the colonial government was disregarding 'native laws or customs' in favour of furthering the Crown's agenda to acquire land for settlement. However, at this time little changed 'on the ground' in the Muriwhenua region and local Māori and the missionaries continued with their shared living arrangements (Waitangi Tribunal 1997, 4). Even so, his dissatisfaction with Crown actions at this time was enough for Panakareao to reverse his view of what colonial governance was going to mean in relation to land, only one year after signing Te Tiriti. 
More significant change followed with the Land Claims Settlement Act (1856), passed within a few years of settlers gaining control of government in 1852 . With settler interests dominating the colony's government, the interests of the Colonial Office and those concerned with 'aboriginal protection' were more easily ignored. The Land Claims Settlement Act led to the establishment of a further commission, under Francis Dillon Bell, to definitively survey and clarify the boundaries of settler, Māori and 'surplus' Crown lands. According to the Waitangi Tribunal (1997, 159-60), the effect of Commissioner Bell's work, in Muriwhenua at least, was to sever the interests of the missionaries and Māori. Bell knew that Māori would resist any Crown surveyors and established a scheme for the settlers to survey their own lands, incentivising them with offers of additional lands, beyond those allowed by earlier commissions, as 'allowances' for completing the surveys. This resulted in a number of the early settlers, including missionaries, receiving landholdings well in excess of the 2,500 acre limit (Waitangi Tribunal 1997, 132-4). Remaining lands, as earlier, were deemed 'surplus' Crown lands and only small reserves, if any, were set aside for Māori, despite the established understandings between early settlers and Mãori that they would share the land, despite Hobson's declaration at Waitangi that 'lands unjustly held would be returned' (Waitangi Tribunal 1997, 155), and despite subsequent assurances from Captain Fitzroy that surplus lands would 'revert to the natives themselves' (Waitangi Tribunal 1997,347, nt9). The result was that in the Kaitaia-Awanui area, the prime agricultural land on which most Māori of the area lived (Waitangi Tribunal 1997, 170), the land was split almost 50/50 between six settlers and the government, with Māori retaining a little over $1 \%, 446$ acres in total (based on figures provided by the Waitangi Tribunal 1997, 163).

Thus by 1865 , Māori in the area, which before colonial settlement had been a fertile land of gardens and swampland supporting around 8000 people, had been significantly dispossessed by a settler legal process that ignored both Māori law and the original agreements made between the missionaries and Māori (Waitangi Tribunal 1997, Chp 6). Crucial to this process was the imposition of Western conceptions of land as private and alienable property, constructions that in turn depended on the practices of mapping and surveying to bring parcels of land into being that could then be sold as property on the market (see Byrnes, 2001). Rather than representing a pre-existing reality, these colonial maps (and surveys) created new forms of land and brought a new, colonial configuration of people and place into being.

The result was Māori 'marginalisation on the rims [of the area] - politically, socially and economically' (Waitangi Tribunal 1997, 205). As the Tribunal con- 
clude from their investigation of land transactions in Muriwhenua up until 1865:

the historical record points to one consistent theme: a desire to acquire as much Māori land as could be, to limit Māori lands as far as possible, and to remove Māori entirely from the town areas and the nearby fertile flats and valleys. (1997, 333-4)

Again, it was some time before these alienated lands were actually settled by Pākehā, but by the turn of the twentieth century the effects were well and truly being felt and the Tribunal reports that:

the hapū of Muriwhenua were in a parlous condition. They were in every sense living on the fringes, a marginalised and impoverished people on uneconomic perimeter lands. They were struggling to survive, both individually and as a people, and the effect was to disperse the people and destabilise the polity of the hapū. $(1997,335)$

\section{Kaitaia's Agricultural and Pastoral showgrounds}

With land surveys complete and titles 'settled', the early settlers, including the missionaries, began in the 188 os to break up their land. The CMS set aside a 4 acre site for a school in 1884 (Matthews, 1956, 22) and sold portions to incoming settlers who began to arrive in numbers from this time (including some of my own Bell ancestors). The land on which Te Ahu now stands was sold to the Mangonui County Agricultural and Pastoral (A\&P) Association in 1888, thus again reconfiguring this land and associated relations between people. The early establishment of an A\&P Association in 1885, an organisation devoted to the improvement and celebration of farming (see http://www.teara.govt.nz/ en/1966/agricultural-societies), indicates the importance of the agricultural economy to the incoming settlers, and served as an important social organisation for the community. A hall was erected on the site and the first A\&P show held there in 1890 (Shepherd 1988, 6). Thus began a very long period of occupation of the site by the Association that extended until the 1970s.

Reading Robin Shepherd's history of the Mangonui County A\&P Association, the role played by the Matthews family is clearly evident, with six of 26 Association presidents during this 100-year period being Matthews family members, in addition to occupying other positions on the Association. I have not searched the total archive of Association members in an attempt to trace Mãori involvement, but there were definitely some Mãori members in the first decade of the Association, many from the local Te Rarawa hapu at Pukepoto. Ngarama 
Patana, Leopold Busby, John Murray (Hone Mare), Job (Hopa) Taomia, Noble Kemp, Roli Rakana, Kingi Rakena and Hetta Rameka are all names that appear in the records up until 1905. Over time however, Māori involvement in the leadership of the Association appears to have waned, with no Māori committee members listed between 1905 and $1908 .{ }^{10}$ This is in keeping with the overall landlessness of Māori in the north and the uneconomic nature of many Māori landholdings in the early twentieth century.

Alongside the processes of Pākehā community-building and economic development around the turn of the twentieth century, the Māori communities of Muriwhenua were suffering the effects of economic, political and social marginalisation. John Koning and Bill Oliver describe how the alienation of Muriwhenua Māori from the land drove many to gum digging, where a system of 'debt peonage' to gum dealers did nothing to alleviate their impoverished position. ${ }^{11}$ They note further that throughout the late nineteenth century and well into the twentieth the government did little to promote Māori economic well-being (Koning and Oliver 1993, 6-12; also Geiringer 1992). Policies to develop the remaining Māori landholdings did nothing, or little, for Māori. Instead, they involved the establishment of Land Councils and Boards and frequently leasing of Māori land, usually to Pākehā farmers. Remaining Māori landholdings were fragmented, marginal and remote, often with no roading access to enable produce to be transported for sale (Geiringer 1992, 14). As Judith Binney and Vincent O'Malley $(2015,299)$ note, 'a dual economy was developing' in the 1890-1920 period, in which Pākehā received state support for development while Māori interests and needs were generally ignored.

In the 1930s, Sir Apirana Ngata's land reform movement did help some Māori families establish small farming enterprises, but Aroha Harris (2015, 324-6) records that in the north these were often too small to provide an entire family livelihood. In contrast, Pākehā landowners received various forms of government support in the form of roading development, swamp drainage and so on (Koning and Oliver 1993,15-18). Koning and Oliver recount the distressing story of the resulting high rates of mortality and morbidity amongst the Māori community from the late 1800 s well into the twentieth century as a result of diseases of poverty. They recount also the lack of governmental response despite repeated pleas (over decades) from various officials for medicines and health professionals to be sent north. At the same time, consistently from the 1830s, Muriwhenua Mãori protested the loss of their lands and their impoverished state through whatever avenues were open to them, including appeals to courts, letters to politicians, parliamentary petitions, protest actions and refusals to pay taxes (see Puckey 2011 for a detailed history). 
In 1973 a 21-year lease was signed with Kaitaia Borough Council for the portion of land on which Te Ahu now stands (Shepherd 1988, 25). This year also, a fundraising campaign began, the local community needing to raise a portion of the funds to secure Borough Council support and funding for a new Community Centre to replace the dilapidated A\&P hall. In 1974 ownership of the land was transferred to the Kaitaia Borough Council and Prime Minister, Bill Rowling, opened the new Kaitaia Community Centre in 1975. At the same time, local iwi were pursuing a plan to build a town marae (meeting complex) in Kaitaia and were encouraged to combine forces with the Community Centre campaign to build a facility that would serve both needs. However, as Haami Piripi explained, the outcome yet again marginalised the Mãori community in favour of what was important to Pākehā:

When the community centre was built my parents were part of the initiative to build a marae in Kaitaia. [...] The people building the community centre approached the [people of the] marae and said "We can't build both. So why don't you guys chuck your money in with us and we'll build a community centre for everybody?" The thought was good, the gesture was great, but it wasn't actually fulfilled. What happened was the marae people became subsumed by the Kaitaia community psyche and we became marginalised within the building of the project and certainly within the operation of it. And for thirty years that's really how it's been. (Interview, 21/4/12)

Prior to the establishment of $T e A h u$ however, one section of land did return to Mãori hands as a result of the Treaty settlements process. During WWI in 1917 , a portion of the A\&P land was taken by the Ministry of Public Works to establish a Drill Hall, the Church being compensated $£ 50$ for this land at the time. In 1992 this land was sold to Te Rūnanga o Te Rarawa in anticipation of their Treaty settlement, under the provisions of the State Owned Enterprises Act 1986 that made unused Crown lands available for return to iwi as part of a settlement (the Te Rarawa Settlement Act was finally passed in 2015).

This recent return of land aside, throughout the era of the A\&P showgrounds and the establishment of the Community Centre, the Te $A h u$ site remained a significant community meeting place, but now one reflecting the dominance and interests of Pākehā settlers. The move from mission station to A\&P showgrounds epitomised central settler interests, from 'converting' and 'civilising' Māori to establishing an agricultural economy on Māori land. Māori continued to participate in the meetings on this site, but as farmers and families within a Pākehā-dominated community. However, towards the end of this era 
things again began to change, first with the attempt to have the Community Centre act as a town marae, and then with the return of a small portion of the old missionary estate to Te Rarawa, giving the iwi an important foothold in the development of what was to become Te Ahu.

TE AHU

In 2004 the Far North Regional Museum Trust set out to secure funding and political support for a new building to house the local museum. By 2007 significant funding had been secured from the Asв Community Trust and others, the Far North District Council was on-board and a charitable trust was set up to lead the project. Iwi representatives were involved in the development from the outset and in 2010 Te Rarawa Chair and Te Ahu Charitable Trust member, Haami Piripi, wrote a 'Discussion Paper on Iwi Engagement' for the Trust. This paper set out a vision for a partnership of 'the seven peoples of the north' (the five Muriwhenua iwi, Pākehā and Dalmatians) to permeate all levels of the centre's operations - the ownership, governance, management and operations (Piripi 2010).

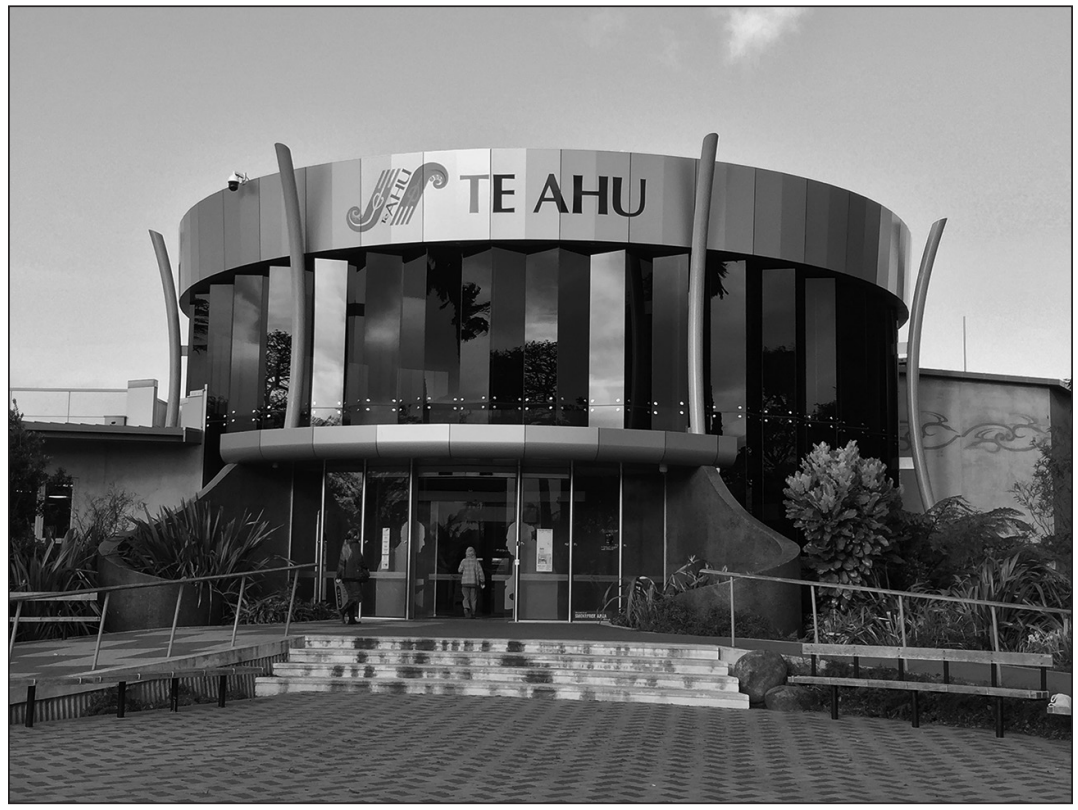

Figure 3. Te Ahu (Photograph: Avril Bell) 


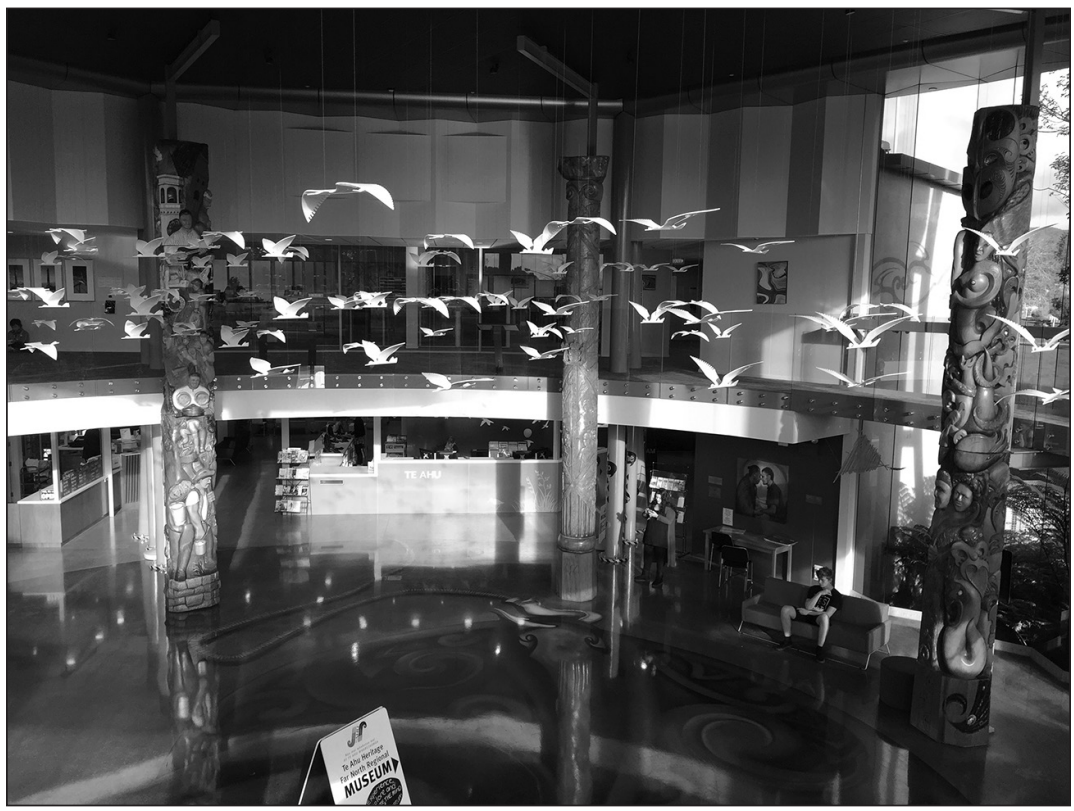

Figure 4. The central atrium and pou, Te Ahu (Photograph: Avril Bell)

However, this partnership vision was not realised during the remainder of the building phase, nor has it been in the four years since Te Ahu opened in 2012, although Te Rarawa has continuously had a presence on the Te Ahu Charitable Trust, and Ngati Kahu did also for a period. ${ }^{12}$ The presence of these two iwi trustees is in itself significant, a recognition of the mana whenua (territorial authority) claims of these iwi that has not been evident in the history of the site since the era of the missionaries. Beyond these two governance positions, each of the five iwi has been involved in the development to some extent, via consultation processes, and particularly via the creation of the seven pou (carved posts) to circle the atrium of the building, one for each of the seven peoples. ${ }^{13}$

Shortcomings in meeting the partnership vision aside, there is huge local pride in the Te Ahu complex - in its design and artwork and the resources and technology housed there. Surveying visitors in the opening week of Te Ahu, the most common response was 'awesome' and visitors were impressed at Kaitaia having such a beautiful building (Bell and Mackey 2012; also see Bell and McKinley 2013). The pou in particular powerfully symbolise the existence and claim to belonging of the seven people and the importance of their presence is 
not to be underestimated (see Bell 2015). Te Ahu is then the latest configuration in the long function of this place as a meeting place, and one in which, once again, Muriwhenua iwi are back at the table and back in the heart of the Kaitaia area, although much work remains to be done to consolidate and extend this iwi presence, which still falls far short of the partnership vision that catalysed their involvement early in the project.

\section{UNSETTLED HISTORIES, HAUNTING PRESENCES}

The presence of ghosts within $T e A h u$ is one indicator of this work to be done and that the complex remains 'in process' as a 'spatio-temporal event' (Massey 2005, 131). I was first told of these ghosts in conversation with one of my research participants in July 2015, and have subsequently talked to others who work within the complex who have confirmed that there are ghosts at Te Ahu. A shadowy Māori male figure has been captured on Сстv footage at the door at night, but not on any of the footage that would record him approaching or leaving. A woman has been seen in the atrium of the building during the daytime. I have been told that at times the doors have inexplicably been found open in the morning, and that there have been electrical problems that tradespeople can find no explanation for and that spontaneously correct themselves. Finally, well-known TV psychic Sue Nicholson (http://www. suenicholson.co.nz/), visiting the complex to give a show, reportedly told one of the staff that she could sense there had been a lot of conflict on this site. In these conversations I have been reminded that this is a site on which people died, in both pre-colonial and colonial times, that there was a burial ground in the area, and that taonga (treasured possessions) were buried with various people on the site. I have been told also that some of the ghosts that haunt $\mathrm{Te}$ $A h u$ are associated with the land, and others are associated with the museum and the taonga housed there.

There are many ways to read the presence of such indigenous ghosts. From within mātauranga Māori (Māori knowledge) a number of terms signify ghostly or spiritual dimensions of being, such as atua, wairua and kēhua, the latter being closest to the English 'ghost'. According to Hirini Mead (2003, 148), spirits lingering after death are troubling ghosts for some, but for many are considered comforting ancestral presences remaining in culturally significant sites, reluctant to leave the land of the living. As Misha Kavka $(2014,230)$ argues, the ongoing spiritual presence of ancestors is embraced 'as the basis of all knowledge of self, community and land'. They are not 'out of place' but in and of place, and mark the living and ongoing connection of the community to place. So from within mātauranga Māori the ghosts of $T e A h u$ point to the 
ongoing presence of the Māori past of place, to the continuing liveliness of the past in the present, in short, to the ongoing existence of Te Ao Māori (the Māori world).

For settler peoples indigenous ghosts resonate differently, typically read as a haunting, uncanny, and unsettling return of a repressed past. Ghosts, from this perspective, point to injustices that keep these spirits restless. Frequently then, indigenous ghosts are read as haunting the settler and marking the injustices of colonial settlement. ${ }^{14}$ Derrida argues that, in the pursuit of justice, we must learn to speak with, and especially to listen to these ghosts (2006 [1993], 221) and to engage in 'mourning work' (94) for the histories of injustice their presence marks. At the same time, ghosts are unknowable and can never finally be settled, or settled with (169-170), but must be kept close by (109). The provocation of the ghost then is to prompt us to do more, to act and be otherwise, to work against the hegemonic settlements of our time. Taking the Māori and Derridean views together, Te Ahu's ghosts mark the coevalness of Māori and Pākehā temporalities, working against the suppression of Te Ao Māori in the present.

Ghostly presences at $\mathrm{Te} A h u$ act also as a reminder of Panakareao's speech at the signing of Te Tiriti. The speech itself might be said to be ghostly, ${ }^{15}$ with the original Māori not recorded and only the English translation remaining. It is then undecidable what exactly he said that was translated as 'the shadow of the land. Further, the argument Panakareao made depended on distinguishing shadow/spirit and 'substance', the shadow of the land referring to spiritual or protective aspects of the relation to land. ${ }^{16}$ Within a year he had changed his mind, coming to the view that the Treaty led to a situation in which, while the spirit remained with Mãori, the Crown was taking the substance. Our society today is haunted by the truth of this, by the injustices that were enacted and by the continuing spiritual connection between Māori and the land. As Stephen Turner $(2002,41)$ has put it:

The problem is not ghosts of the past, but the idea of the past that will not die: an idea that the past is, well, perfectly present, that the place itself is still in some sense tapu, strictly speaking, still possessed.

The ghosts of $T e A h u$ then point to the continuing possession of this place by iwi, to the unsettled nature of the histories of the area, including the history of Te Ika Hunuhunu, ${ }^{17}$ and to the injustices by which the substance of the land was taken through the betrayal of promises made at the Treaty signing. To learn to live with these ghosts is to mourn this history, to attend to what they 
might have to teach us about the relation of the past and present of place and to consider what must be done in the pursuit of justice for past wrongs and also for the communities of the future.

\section{CONCLUSION}

Massey $(2005,139)$ argues that a place is an event, open-ended and in process, where spatial narratives meet up or form configurations, conjunctures of trajectories which have their own temporalities [...] where the successions of meetings, the accumulation of weavings and encounters build up a history. It's the returns [of people, animals, seasons, etc] and the very differentiation of temporalities that lend continuity. But the returns are always to a place that has moved on, the layers of our meeting intersecting and affecting each other; weaving a process of space-time. [...] 'Here' is an intertwining of histories in which the spatiality of those histories $[\ldots]$ is inescapably entangled.

Te $A h u$ is made up of the intersecting and interwoven trajectories of the Awanui River, of iwi, of Ika Hunuhunu, of Pākehā, of Dalmatians, of warriors, farmers, families and political leaders, and of many more people and stories of Te Ao Māori and Te Ao Pākehā than can be recorded here or can ever be captured. And, as Massey suggests, while a place is always changing, historical layers continue to make their presence felt, new meetings are both new and returns. The Awanui River continues to make its past presence felt in the need to drive unusually deep piles to form the foundation of Te Ahu. The presence of Panakareao and the missionaries continues through the pou and in the museum, but more profoundly in the ongoing relations between, and trajectories of, their descendants and wider communities, haunted by the commitments made on April 28, 1840, and the injustices that followed.

The 'event of place' for Massey also lies in the politics of encounter, in 'the question of our living together' $(2005,151)$. She argues that 'the thrown togetherness of place demands negotiation', and talks of 'the ethics and the responsibility of facing up to the event' (Massey 2005, 141). The long history of meeting and negotiation between peoples at Te Ahu continues in the present, and with it the struggle by iwi to bring into being Panakareao's vision of continuing tribal mana whenua and mutually beneficial co-existence with Pākehā. The history of Te Ika Hunuhunu/Te Ahu is not over, but is lively, present and demanding, gathered into this new building and the entwined lives of the 'seven peoples' of the north. 
NOTES

1 Avril Bell is a Senior Lecturer in Sociology at the University of Auckland, New Zealand. Her research interests centre on settler colonialism, indigenous-settler relations and possibilities for decolonisation. Her book, Relating Indigenous and Settler Identities: Beyond Domination, addresses these issues in four settler societies - Australia, Canada, New Zealand and the United States of America.

Email: a.bell@auckland.ac.nz

2 The final footprint of the building also extends onto Te Rarawa land and the iwi (tribe) moved their Rūnanga offices to accommodate the development of Te Ahu.

3 My thanks to the funders who supported this work - the Massey University Research Fund [Grant RM15947] and the Faculty Research Development Fund of the University of Auckland [Grant 3702644].

4 The first two missionaries to the area were the Reverend Joseph Matthews and William Gilbert Puckey. Puckey Ave lies roughly parallel to Matthews Ave on the other side of the town's main street.

5 In her history of the area, Florence Keene (1997, 9-10) records that Te Ahu was the name of the area where the mission (and the present town) was situated, while Kaitaia was the name of a valley further south, now known as Victoria Valley. Keene also suggests that Joseph Matthews did not like the name Te Ahu, although why is unclear, and encouraged the change to Kaitaia (also see Matthews 1956,6 ). In this paper I italicise the name of the building to distinguish between reference to Te Ahu as historical place and Te Ahu as contemporary building.

6 As the Waitangi Tribunal $(1997,17)$ note, 'The wealth of names [in Muriwhenua] highlights the intensity of settlement and the people's intimacy with the land. It seemed, on hearing evidence, that there was a name for every fishing ground, reef, and prominent ledge at sea, and for every feature of the land'.

7 The five iwi are Ngāti Kuri, Te Aupōuri, Ngāi Takoto, Te Rarawa and Ngāti Kahu. While it is Te Rarawa who own some of the land on which Te Ahu stands and they claim tribal authority in this area, so too do Ngāti Kahu. More broadly, Treaty settlements agreed to during 2012-13 by all of the Muriwhenua iwi, barring Ngāti Kahu, involve recognition by the Crown of the continuing authority of each of the iwi in their territory. 
8 The Tribunal discusses tuku whenua in some detail (see 1997, 68, 73-6, 106-8).

9 This overview of the Treaty signing draws from a range of sources - Belgrave (2005, 107-10), Orange (2011, 83-4), Puckey (2011, 37-44), and Waitangi Tribunal (1997, 111-5).

10 See Mangonui County A\&P Association Minute Books, 1891-96, 1896-1905, 1905-08 - Files A17/2/1, A17/2/2 and A17/2/3 respectively. Te Ahu Heritage Museum and Archives.

11 The dealers were also storekeepers 'and often publicans, and ... sometimes owned the land upon which the diggers worked. Dealers had a monopoly and were able to drive one set of prices down [for gum] and the other up [for food and supplies]; they often acted in collusion to deprive sellers of the advantages of "shopping around". Receipts to diggers were often not enough to meet the credit already extended; cash surpluses were not paid out but carried forward against future store purchases. When prices were low diggers fell deeper into debt; when they rose debt eliminated any advantage' (Koning and Oliver 1993, 7; also see Božić-Vrbančić 2008, on the effects of this system on Dalmatian gum diggers).

12 The story of the barriers to this partnership vision remains to be told in another paper.

13 Six of the seven are in place at the time of writing. Paul Marshall (Ngāti Kahu) has been the tohunga whakairo (master carver) with overall responsibility for the pou and himself the lead carver of the Te Rarawa, Dalmatian and Ngati Kahu pou. Duncan Kapa (Te Aupouri) was the lead carver of the Te Aupouri and Ngāi Takoto pou, and Peter Griffiths of the Pakehā pou. The Ngāti Kuri pou was carved at Te Wānanga Whakairo Rākau-o-Aotearoa in Rotorua under the tutelage of Taonui-a-Kupe (James) Rickard (Ngāti Kuri).

14 The reduction of indigeneity to ghostly presences can alternatively be read as a sign of the success of settler domination (see Bergland 2000; Bell 2014). From this perspective, the ghost signifies the relegation of indigeneity to the past, in direct contradiction of the Mãori view of ghosts marking the continuing presence of the past.

15 My thanks to Barbara Grant for this suggestion and for our conversation about the ideas explored here in relation to the ghostly nature of Panakareao's speech.

16 Expert witnesses to the Muriwhenua claim suggest the word translated as 
'shadow', would have been either 'atakau' or 'ātārangi', both of which suggest a protective or spiritual aspect of a being (Waitangi Tribunal 1997, 112-3).

17 In another paper I address the tension between the histories of Te Ika Hunuhunu and Te Ahu in more detail, arguing that the contemporary Te Ahu both resurfaces and risks eliding the history of Te Ika Hunuhunu (Bell, in preparation).

\section{REFERENCES}

Ballara, Angela. 2003. Taua: 'Musket Wars', 'Land Wars' or Tikanga? Warfare in Māori Society in the early Nineteenth Century. Auckland: Penguin Books.

Belgrave, Michael. 2005. Historical Frictions: Mãori Claims and Reinvented Histories. Auckland: Auckland University Press.

Bell, Avril and Eva Mackey. 2012. Te Ahu First Impressions - 'Awesome!'. Research report for Te Ahu Charitable Trust. Auckland: University of Auckland.

Bell, Avril and Michael McKinley. 2013. Te Ahu Visitors' Survey. Research report for Te Ahu Charitable Trust. Auckland: University of Auckland.

Bell, Avril. 2014. Relating Indigenous and Settler Identities: Beyond Domination. Basingstoke: Palgrave Macmillan.

Bell, Avril. 2015. 'Entangled Worlds: Ontology and Relationality in a Settler Society’. Paper presented at Space and Place, Inter-Disciplinary.Net conference, Mansfield College, Oxford University, 3-5 September. Available at: http:// www.inter-disciplinary.net/critical-issues/wp-content/uploads/2015/o8/ ABell-sp6-dpaper.pdf

Bell, Avril. (in preparation) 'Decolonizing by Degrees: The Liveliness of Symbols'. In The Vernaculars of Occupation: Settler Colonial Texts Across Borders, edited by Rebecca Weaver-Hightower and Yuting Huang.

Berg, Lawrence D., and Robin A. Kearns. 1996. 'Naming as Norming: "Race”, Gender and the Identity Politics of Naming Places in New Zealand'. Environment and Planning D: Society and Space 14:99-122.

Binney, Judith, and Vincent O'Malley. 2015. 'The Quest for Survival, 1890-1920'. In Tangata Whenua: A History, edited by Atholl Anderson, Aroha Harris and Judith Binney, 280-307. Wellington: Bridget Williams Books. 
Božić-Vrbančić, Senka. 2008. Tarara: Croats and Māori in New Zealand, Memory, Belonging and Identity. Dunedin: Otago University Press.

Byrnes, Giselle. 2001. Boundary Markers: Land Surveying and the Colonisation of New Zealand. Wellington: Bridget Williams Books.

Casey, Edward E. 1996. 'How to Get from Space to Place in a Fairly Short Stretch of Time: Phenomenological Prolegomena' In Senses of Place, edited by Steven Feld and Keith H. Basso, 13-52. Santa Fe: School of American Research.

Derrida, Jacques. 2006 [1993]. Specters of Marx: The State of the Debt, the Work of Mourning and the New International. Translated by Peggy Kamuf. New York: Routledge.

Geiringer, Claudia. 1992. Historical background to the Muriwehnua land claim, 1865-1950. Research report commissioned by the Waitangi Tribunal, wAI 45 , pp. 234.

Gieryn, Thomas F. 2000. 'A space for place in sociology'. Annual Review of Sociology 26:463-496.

Harris, Aroha. 2015. 'Persistence and Resilience, 1920-1945'. In Tangata Whenua: A History, edited by Atholl Anderson, Aroha Harris and Judith Binney, 311-332. Wellington: Bridget Williams Books.

Kavka, Misha. 2014. 'Haunting and the (Im)possibility of Māori Gothic'. In The Gothic and the Everyday: Living Gothic, edited by Lorna Piatti-Farnell and Maria Beville, 225-40. Basingstoke: Palgrave Macmillan.

Keene, Florence. 1977. To the Northward. Whangarei: Advocate.

Koning, John, and W.H. Oliver. 1993. Economic decline and social deprivation in Muriwhenua, 1880-1940. Research report commissioned by the Waitangi Tribunal, wAI 45, pp. 48 .

Marsden, Maori. 1992. 'God, Man and Universe: A Māori View’. In Te Ao Hurihuri: Aspects of Māoritanga, edited by Michael King, 118-137. Auckland: Reed.

Massey, Doreen. 2005. For Space. London: Sage.

Matthews, S.C., and L.J. Matthews. 1939. Matthews of Kaitaia: The Story of Joseph 
Matthews and the Kaitaia Mission. Dunedin: A.H. \& A.W. Reed.

Matthews, Harold S. 1956. The First 100 Years. Kaitaia: Northland Age.

Mead, Hirini Moko. 2003. Tikanga Māori: Living by Māori Values. Wellington: Huia Publishers.

Orange, Claudia. 2011. The Treaty of Waitangi. 2nd ed. Wellington: Bridget Williams Books.

Piripi, Haami. 2010. 'Te Ahu discussion paper on iwi engagement'. Unpublished report for Te Ahu Charitable Trust.

Pratt, Mary Louise. 2008. Imperial Eyes: Travel Writing and Transculturation. 2nd ed. London: Routledge.

Puckey, Adrienne. 2011. Trading Cultures: A History of the Far North. Wellington: Huia Publishers.

Shepherd, Robin L. 1988. A Short History of the Mangonui County Agricultural and Pastoral Association. Kaitaia: Mangonui Agricultural Association.

Turner, Stephen. 2002. 'Being Colonial/Colonial Being'. Journal of New Zealand Literature 20:39-66.

Waitangi Tribunal. 1997. Muriwhenua Land Report. WAI 45. Wellington: GP Productions.

Wellington, Shannon. 2013. 'Building GLAMour: Converging practice between Gallery, Library, Archive and Museum entities in New Zealand Memory Institutions'. PhD diss., University of Victoria, Wellington. 